\title{
Fluorinated Aromatic Amino Acids and its Therapeutic Applications Kiran K Andra*
}

Department of Physiology and Biophysics, SUNY College at Buffalo, USA

\begin{abstract}
Fluorinated amino acids play a significant role in peptides and protein studies. These are known to enhance the stability of proteins folds and serve as valuable analogues for investigation of enzyme kinetics, protein-protein and ligand-receptor interactions. Due to the unique properties of fluorine, fluorinated amino acids are used as a powerful tool to study biological process and to develop anti-cancer reagents and vaccines. Previous reviews cover synthesis and applications of fluorinated amino acids in broad range; this short review provides the importance of fluorinated aromatic amino acids and the impact of fluorine substitution in its aromatic rings that facilitate the study of structure, function and stability of therapeutic proteins and peptides which have great potential for future therapeutic applications.
\end{abstract}

Keywords: Fluorinated amino acids; Therapeutic applications; Analogues

\section{Introduction}

Fluorination became the more radical approach for modification of leading compounds in medicinal chemistry [1,2]. Due to its small size and high electronegativity, fluorine forms a strong covalent bond with carbon, shows a significant impact on neighboring groups that alter the stability and reactivity of the molecules, helps to creates more stable protein folds $[3,4]$. Fluorinated amino acids were synthesized a long time back and showed significant physiological activity [5]. Nevertheless, some of these analogues have more applications than others due to their availability, biological activity and role in protein structure and functions. Several newly synthesized analogues over the past decade have not yet been pursued far enough to study their biological activities (Table 1).

One of the major applications of these analogues is to study protein structure and function. Protein engineering has been restricted to naturally-occurring amino acids. However incorporation of un-natural amino acids into proteins in living cells has been expanded based on the availability and applications in protein engineering and functional studies [6,7]. There are two ways of incorporating fluorinated amino acids into proteins, residue specific and site specific. Depending on the protein and its applications, one of these methods has been used for incorporation of amino acid analogues to study structural and functional properties of protein. For instance, residue specific labeling was used to examine the conformational changes of proteins and for detection of protein-ligand interaction by ${ }^{19} \mathrm{FNMR}$ spectroscopy [8]. Incorporation of fluorinated aromatic amino acids into proteins increased its shelf life compared to the wild type which is one of the great benefits, especially in therapeutic proteins and vaccine studies [9].

Incorporation of theses un-natural amino acids into peptides based vaccines showed an enhanced catabolic stability, since antigenic peptides have short bioavailability [6]. Recent studies showed that fluorinated aromatic acids were able to distinguish the role of aromatic acid in peripheral membrane proteins and integral membrane proteins by destabilizing the cation- $\pi$ interactions which helps to determine the role of particular aromatic amino acids in membrane-protein interaction [10].

\section{Fluoro-Phenylalanine (FPhe)}

One of the most studied fluorinated amino acid is phenylalanine; it has more analogues than any other amino acids (Table 1). Due to its flexibility in the substitution of fluorine in its aromatic ring,
Fluorinated phenylalanine (FPhe) analogues have been successfully incorporated into various proteins and enzymes, both residue specific $[11,12]$ and site specific [13]. First 4-Fluoro phenylalanine (4FPhe) was site specifically incorporated into E. Coli by Furter et al., using PheRS/tRNA ${ }^{\text {phe }}{ }_{\text {amber }}$ pair from Saccharomyes cerevisiae [13]. The major advantage of this method is to introduce analogues non-selectively in any protein irrespective of size which gives better yields [13]. Apart from enhanced protein stability, fluorinated aromatic amino acids also alter the enzymatic activity and help in understanding the mechanistic process. The flexibility of fluorine incorporation has been studied using PvuII endonuclease to illustrate the differential effects of FPhe analogues on stability and activity of the enzyme [14]. Incorporation of 3-Fluoro phenylalanine (3FPhe) in PvuII endonuclease shows similar stability as wild type with two-fold increase in its activity. On the other hand, 2-Fluoro and 4-Fluoro showed poor incorporation and decreased stability with less activity $[14,15]$. This is a good model that shows how fluorinated aromatic amino acid has an impact on enzymes and their catalytic activity.

Most often, therapeutic vaccination procedures used immunogenic peptides that are derived from disease-associated proteins [6] Substitution of FPhe into these peptides sheds more light on its interactions and helps to develop better vaccines. For instance, incorporation of FPhe into immunogenic peptides derived from Wilms Tumor protein (WT1), allowed to study the class I major histocompatibility complex, MHC-peptide complex. The stability of this complex correlates with T-cell response [6]. Overexpression of WT1 protein is identified in various cancerous cells and the peptides obtained from this protein have been used in therapeutic vaccines [6]. Incorporation of 2,3-difluoro-L-phenylalanine showed an enhanced affinity due to increase in hydrophobicity by fluorine substitution [6,15-17].

Likewise FPhe shows significant impact on endomorphin (EM) peptides studies. EM have the longest half-lives compared to all endogenous opioid ligands, but in order to consider them as a potential

*Corresponding author: Department of Physiology and Biophysics, SUNY College at Buffalo, USA, Tel: 13162598613; E-mail: kiranand@buffalo.edu

Received: October 19, 2015; Accepted: December 08, 2015; Published December 11, 2015

Citation: Andra KK (2015) Fluorinated Aromatic Amino Acids and its Therapeutic Applications. Biochem Anal Biochem 4: 235. doi:10.4172/2161-1009.1000235

Copyright: $\odot 2015$ Andra KK, et al. This is an open-access article distributed under the terms of the Creative Commons Attribution License, which permits unrestricted use, distribution, and reproduction in any medium, provided the original author and source are credited. 
Citation: Andra KK (2015) Fluorinated Aromatic Amino Acids and its Therapeutic Applications. Biochem Anal Biochem 4: 235. doi:10.4172/21611009.1000235

Page 2 of 4

\begin{tabular}{|c|c|c|c|c|}
\hline \multirow{2}{*}{ Amino Acid } & \multirow{2}{*}{$\begin{array}{l}\text { Number of Fluorinated } \\
\text { Analogues }\end{array}$} & \multicolumn{2}{|l|}{ *Fluorinated Analogues } & \multirow{2}{*}{ Applications (Ref.) } \\
\hline & & Part I & Part II & \\
\hline Phenylalanine & 17 & $\begin{array}{l}\text { 2-fluoro-Phenylalanine, } \\
\text { 3-fluoro-Phenylalanine, } \\
\text { 4-fluoro-Phenylalanine, } \\
\text { 3,5-difluoro-Phenylalanine, } \\
\text { 3,4-difluoro-Phenylalanine, } \\
\text { 2,3-difluoro-Phenylalanine, } \\
\text { 3,4,5-trifluoro-Phenylalanine, } \\
\text { 2,3,4,5,6-pentafluoro-Phenylalanine }\end{array}$ & $\begin{array}{l}\text { 2,3-difluoro-Phenylalanine, } \\
\text { 2,4-difluoro-Phenylalanine, 2,5-difluoro- } \\
\text { Phenylalanine, 2,6-fluoro-Phenylalanine, } \\
\text { 2,4,6-trifluoro-Phenylalanine, } \\
\text { 2,3,6-trifluoro-Phenylalanine, } \\
\text { 2,4,5-trifluoro-Phenylalanine, } \\
\text { 2,3,4-trifluoro-Phenylalanine, } \\
\text { 2,3,4,5-tetrafluoro-Phenylalanine }\end{array}$ & $\begin{array}{l}\text { 19F-NMR [44], Protein structure and } \\
\text { function [5,6], } \\
\text { Enzymatic studies[14], peptides [18] }\end{array}$ \\
\hline Tryptophan & 9 & $\begin{array}{l}\text { 3-fluoro-Tryptophan, } \\
\text { 4-fluoro-Tryptophan, } \\
\text { 5-fluoro-Tryptophan, } \\
\text { 6-fluoro-Tryptophan, } \\
\text { 7-fluoro-Tryptophan, } \\
\text { 5,7-difluoro-Tryptophan, 5,6,7-trifluoro- } \\
\text { Tryptophan, 4,5,6,7-tetrafluoro- } \\
\text { Tryptophan, }\end{array}$ & 4,7-difluoro-Tryptophan, & $\begin{array}{l}\text { 19F-NMR [45], Protein structure and } \\
\text { function [27], } \\
\text { Enzymatic studies [25,33], Fluorescence } \\
{[21,24]}\end{array}$ \\
\hline Tyrosine & 10 & $\begin{array}{l}\text { 2-fluoro-Tyrosine, } \\
\text { 3-fluoro-Tyrosine, } \\
\text { 2,6-difluoro-Tyrosine, } \\
\text { 2,5-difluoro-Tyrosine, } \\
\text { 2,3-difluoro-Tyrosine,3,5-difluoro- } \\
\text { Tyrosine,2,5,6-trifluoro-Tyrosine,3,5,6- } \\
\text { trifluoro-Tyrosine,2,3,5,6-tetrafluoro- } \\
\text { Tyrosine }\end{array}$ & 2,3,6-trifluoro-Tyrosine & $\begin{array}{l}\text { 19F-NMR [45], Protein structure and } \\
\text { function }[15,32], \\
\text { Enzymatic studies [32], Fluorescence } \\
{[31,34]}\end{array}$ \\
\hline Histidine & 2 & 2-Fluoro-Histidine, 4-Fluoro-Histidine & & $\begin{array}{l}\text { Protein structure and function [40-42], } \\
\text { Enzymatic studies [39] }\end{array}$ \\
\hline
\end{tabular}

* Fluorinated analogues was divided into two parts, Part I analogues has been used in various applications [15] and Some of Part II analogues are commercially available and no significant research studies have been reported.

Table 1: Fluorinated aromatic amino acid analogues.

\begin{tabular}{|l|c|}
\hline Fluorinated analogue & pKa \\
\hline 2-fluro-Tyrosine & 9 \\
\hline 3-fluro-Tyrosine & 8.4 \\
\hline 2,6-difluro-Tyrosine & 8.1 \\
\hline 2,5-difluro-Tyrosine & 7.6 \\
\hline 2,3-difluro-Tyrosine & 7.6 \\
\hline 3,5-difluro-Tyrosine & 6.8 \\
\hline 2,5,6-trifluro-Tyrosine & 6.6 \\
\hline 3,5,6-trifluro-Tyrosine & 6.1 \\
\hline 2,3,5,6-tetrafluro-Tyrosine & 5.2 \\
\hline
\end{tabular}

Table 2: The position and number of fluorine atoms change the pKa of hydroxyl group of fluorinated tyrosine.

therapeutic drugs it is important to increase their ability to enter the central nervous system and their resistance to enzymatic degradation $[18,19]$. Incorporation of $4 \mathrm{FPhe}$ and other un-natural amino acids into $\mathrm{EM}$ increased its affinities for $\mu$-opioid receptor in receptor binding assay [18].

\section{Fluro-Tryptophan and Fluro-Tyrosine}

Fluorinated tryptophan and tyrosine have not been used directly into therapeutic application but enzymatic studies using these analogues show substantial impact on its function. Fluorine substitution at different positions on indole ring of tryptophan affects its polarities that lead to an increased charge separation $[15,20]$. Out of all single fluorine substituted tryptophans, these 3 analogues, 4-Fluoro tryptophan (4FTrp), 5-Fluoro tryptophan (5FTrp) and 6-Fluoro tryptophan (6FTrp) has been used extensively due to their biological properties. 4F-Trp was shown to abolish intrinsic tryptophan fluorescence, absorbance shifted to blue [21] due to its exceptionally low fluorescence quantum yields $[22,23]$. while the remaining analogues managed the changes in absorbance and emission maxima [22,24]. Hence, 4FTrp can be used as a non-fluorescent analogue to study the contribution of tryptophan fluorescence in the protein [24-26]. FTrp analogues has

been used extensively to study conformational changes and proteinligand binding [27]. however very few studies has been reported in the therapeutic area. Cytostatic and cytotoxic effects of these analogue on MCF-7 cell line, showed that fluorinated tryptophan, tyrosine, and phenylalanine holds cytostatic activities, which can be used as a potential chemotherapeutics [28]. In vitro studies of these amino derivatives showed $\mathrm{IC}_{50}$ values $(3-15 \mathrm{~mm}$ ) comparable to the known anticancer agents [28-30].

Fluorinated tyrosines are more hydrophilic due to strong electron withdrawing inductive effect that increases the acidity of hydroxyl group. The position and number of fluorine atoms change the pKa of hydroxyl group of fluorinated tyrosine (Table 2). Since the pKa changes upon fluorination, fluorinated tyrosines were used as a biological probe to study the role of tyrosine in enzymatic process. 3-Fluoro tyrosine (3FTry) showed significant impact on glutathione S-transferase (GST) and fluorophore, green fluorescent proteins (GFP). In the case of GST, 3FTry helps to identity the location of mechanistic proton of the enzyme-glutathione binary complex [31]. 3FTry increased the acidity of hydroxyl group in the active site and decreased the catalytic activity towards 1-chloro-2,4-dinitrobenzene [32], whereas substitution of 5FTrp increased the turnover number of 1-chloro-2,4-dinitrobenzene compared to the wild type $[25,33]$. Introducing fluorinated tyrosine in the active of GST shifts the proton location and shows protonated Glutathione [15,33]. Incorporation of 3FTry into GFP increased its stability at higher $\mathrm{pH}$ compared to WT-GFP, indicates that 3FTry labeled GFP can be used as a pH sensor [34]. These studies clearly shows that the impact of fluorinated aromatic amino acids on enzymes particularly when they are present in the active site.

\section{Fluoro-Histidine}

Histidine is one of most important amino acids in terms of protein function and catalytic action of enzymes. It is challenging to study the role of histidine in biological processes because of its size, shape 


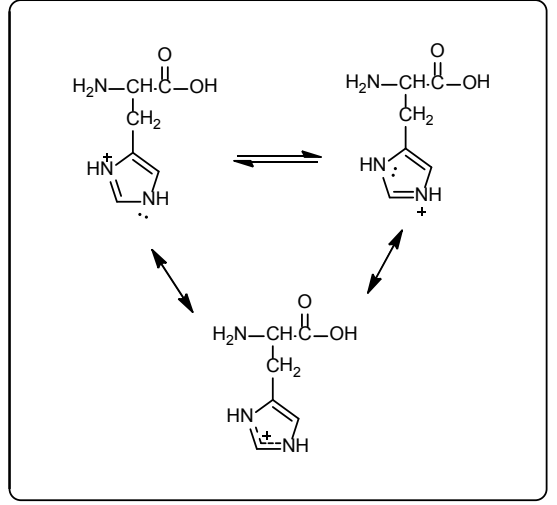

Figure 1: Resonance structure of protonated histidine side chain.

and tendency to form hydrogen bonds and salt bridges at local $\mathrm{pH}$ environment $[35,36]$. Imidazole ring in histidine is mostly protonated and is stabilized by a resonance structure (Figure 1). Because of the $\mathrm{pK}_{\mathrm{a}}$ of the imidazole ring in histidine, protonation and de-protonation can occur within the physiological $\mathrm{pH}$. Substitution of fluorine atom at $\mathrm{C}$ [2] position, pulls the shared electrons from both the nitrogen atoms in the ring towards the central carbon atom, resulting in the change of bond angles and bond lengths which closely resemble the protonated form of histidine [37]. Moreover, fluorination of histidine was unable to protonate at physiological $\mathrm{pH}$, due to a greatly reduced $\mathrm{pKa}$ of the side chain from 6 (Histidine) to $\sim 1.2$ (2-Fluoro histidine, 2FHis) and $\sim 1.7$ (4-Fluoro histidine, 4FHis) [15,38].

Because of its low pKa value, 2FHis served as a valuable analogue to study the structure and function of membrane proteins and enzymes [39]. Anthrax toxin protective antigen (PA), membrane protein binds to its cellular receptor and forms heptameric or octameric pores, which allows the entry of enzymatic moieties (Edema factor, EF or Lethal factor, LF) into the cytosol. This whole process depends on conformational changes that occur from prepore to pore at low $\mathrm{pH}$. Initially it was hypothesized that histidine protonation triggers the pore formation; however, later studies with incorporation of $2 \mathrm{FHis}$ showed that pore formation is independent of histidine protonation and also 2FHis increases the stability of PA [40]. Translocation studies in planner lipid bilayers showed that 2F-His PA was not able to translocate LF through the pores into the cytosol. These studies indicate that $2 \mathrm{FHis}$ pore is biologically inactive, agrees with the conclusion that histidine plays a role in translocation, but does not alter the pore formation in the absence of the receptor $[40,41]$. Many research groups are working on PA to develop a better and stable vaccine for anthrax [42]. Recent studies on 2FHis PA (structural stability and dynamic properties) by using various biophysical techniques suggests that 2 FHis PA can be used as a potential candidate for anthrax vaccine [43-45].

\section{Conclusion}

This short review covered the therapeutics applications of most studied fluorinated aromatic amino acids analogues which helps to understand their role in protein structure and function. Selective fluorination of amino acids make the analogues, a unique tool to study the stability, structure and function of proteins. These fluorinated aromatic amino acids analogues showed cytostatic activities and can be used as potential chemotherapeutics as well as in vaccine development.

\section{References}

1. Müller K, Faeh C, Diederich $F(2007)$ Fluorine in pharmaceuticals: looking beyond intuition. Science 317: 1881-1886.
2. Purser S, Moore PR, Swallow S, Gouverneur V (2008) Fluorine in medicinal chemistry. Chem Soc Rev 37: 320-330.

3. Sutherland A, Willis CL (2000) Synthesis of fluorinated amino acids. Nat Prod Rep 17: 621-631.

4. Yoder NC, Kumar K (2002) Fluorinated amino acids in protein design and engineering. Chem Soc Rev 31: 335-341.

5. Filler R (1960) Fluorinated Aromatic Amino Acids. I. o-, m-, and p-Trifluoromethylphenylalanines. The Journal of Organic Chemistry 25: 733-736.

6. Gómez-Nuñez M, Haro KJ, Dao T, Chau D, Won A, et al. (2008) Non-natural and photo-reactive amino acids as biochemical probes of immune function. PLoS One 3: e3938.

7. Noren CJ, Anthony-Cahill SJ, Griffith MC, Schultz PG (1989) A general method for site-specific incorporation of unnatural amino acids into proteins. Science 244: 182-188.

8. Mishra NK, Urick AK, Ember SW, Schönbrunn E, Pomerantz WC (2014) Fluorinated aromatic amino acids are sensitive 19F NMR probes for bromodomain-ligand interactions. ACS Chem Biol 9: 2755-2760.

9. Budisa N, Wenger W, Wiltschi B (2010) Residue-specific global fluorination of Candida antarctica lipase B in Pichia pastoris. Mol Biosyst 6: 1630-1639.

10. He T, Gershenson A, Eyles SJ, Lee YJ, Liu WR, et al. (2015) Fluorinated Aromatic Amino Acids Distinguish Cation-l̈€ Interactions from Membrane Insertion. J Biol Chem 290: 19334-19342.

11. MUNIER R, COHEN GN (1959) [Incorporation of structural analogues of amino acids into bacterial proteins during their synthesis in vivo]. Biochim Biophys Acta 31: 378-391.

12. Wiltschi B (2012) Expressed protein modifications: making synthetic proteins. Methods Mol Biol 813: 211-225.

13. Furter R (1998) Expansion of the genetic code: site-directed p-fluorophenylalanine incorporation in Escherichia coli. Protein Sci 7: 419-426.

14. Dominguez MA Jr, Thornton KC, Melendez MG, Dupureur CM (2001) Differential effects of isomeric incorporation of fluorophenylalanines into Pvull endonuclease. Proteins 45: 55-61.

15. Salwiczek M, Nyakatura EK, Gerling UI, Ye S, Koksch B (2012) Fluorinated amino acids: compatibility with native protein structures and effects on proteinprotein interactions. Chem Soc Rev 41: 2135-2171.

16. Piepenbrink $\mathrm{KH}$, et al. (2009) Fluorine substitutions in an antigenic peptide selectively modulate $\mathrm{T}$-cell receptor binding in a minimally perturbing manner. The Biochemical journal 423: 353-361.

17. Doubrovina ES, Doubrovin MM, Lee S, Shieh JH, Heller G, et al. (2004) In vitro stimulation with WT1 peptide-loaded Epstein-Barr virus-positive B cells elicits high frequencies of WT1 peptide-specific T cells with in vitro and in vivo tumoricidal activity. Clin Cancer Res 10: 7207-7219.

18. Mallareddy JR, Borics A, Keresztes A, Kövér KE, Tourwé D, et al. (2011) Design, synthesis, pharmacological evaluation, and structure-activity study of novel endomorphin analogues with multiple structural modifications. Journal of medicinal chemistry 54: 1462-1472.

19. Mallareddy JR (2012) Design, Synthesis and Pharmacological Evaluation of Novel Endomorphin Analogues with Multiple Structural Modifications. PhD Dissertation (Hungarian Academy of Sciences).

20. Xu ZJ, Love ML, Ma LY, Blum M, Bronskill PM, et al. (1989) Tryptophanyl-tRNA synthetase from Bacillus subtilis. Characterization and role of hydrophobicity in substrate recognition. J Biol Chem 264: 4304-4311.

21. Bronskill PM, Wong JT (1988) Suppression of fluorescence of tryptophan residues in proteins by replacement with 4-fluorotryptophan. Biochem J 249: 305-308.

22. Wong CY, Eftink MR (1998) Incorporation of tryptophan analogues into staphylococcal nuclease: stability toward thermal and guanidine- $\mathrm{HCl}$ induced unfolding. Biochemistry 37: 8947-8953.

23. Hott JL, Borkman RF (1989) The non-fluorescence of 4-fluorotryptophan Biochem J 264: 297-299.

24. Minks C, Huber R, Moroder L, Budisa N (1999) Atomic mutations at the single tryptophan residue of human recombinant annexin $\mathrm{V}$ : effects on structure stability, and activity. Biochemistry 38: 10649-10659. 
Citation: Andra KK (2015) Fluorinated Aromatic Amino Acids and its Therapeutic Applications. Biochem Anal Biochem 4: 235. doi:10.4172/21611009.1000235

25. Odar C, Winkler M, Wiltschi B (2015) Fluoro amino acids: a rarity in nature, yet a prospect for protein engineering. Biotechnol $\mathrm{J}$ 10: 427-446.

26. Andra KK (2013) Fluorescence studies on anthrax protective antigen pore formation and in the presence of the host recepotor, CMG2.

27. Jenkins BG, Lauffer RB (1990) Detection of site-specific binding and co-binding of ligands to human serum albumin using 19F NMR. Mol Pharmacol 37: 111118

28. Giese C, Lepthien S, Metzner L, Brandsch M, Budisa N, et al. (2008) Intracellular uptake and inhibitory activity of aromatic fluorinated amino acids in human breast cancer cells. ChemMedChem 3: 1449-1456.

29. Lu DY, Huang M, Xu CH, Yang WY, Hu CX, et al. (2005) Anti-proliferative effects, cell cycle G2/M phase arrest and blocking of chromosome segregation by probimane and MST-16 in human tumor cell lines. BMC Pharmacol 5: 11.

30. Margiotta N, Papadia P, Lazzaro F, Angelis FD, Crucianelli M, et al. (2005) Platinum-based antitumor drugs containing enantiomerically pure alphatrifluoromethyl alanine as ligand. Journal of medicinal chemistry 48: 7821-7828.

31. Zheng Y-J (1997) Role of Active Site Tyrosine in Glutathione S-Transferase: Insights from a Theoretical Study on Model Systems. J. Am. Chem. Soc 119:1523-1528.

32. Parsons JF, Armstrong RN (1996) Proton configuration in the ground state and transition state of a glutathione transferase-catalyzed reaction inferred from the properties of tetradeca(3-fluorotyrosyl) glutathione transferase. J. Am. Chem. Soc 118: 2295-2296.

33. Parsons JF, Xiao G, Gilliland GL, Armstrong RN (1998) Enzymes harboring unnatural amino acids: mechanistic and structural analysis of the enhanced catalytic activity of a glutathione transferase containing 5-fluorotryptophan Biochemistry 37: 6286-6294.

34. Ayyadurai N, Prabhu NS, Deepankumar K, Kim A, Lee SG, et al. (2011) Biosynthetic substitution of tyrosine in green fluorescent protein with its surrogate fluorotyrosine in Escherichia coli. Biotechnol Lett 33: 2201-2207.
35. Kirsch JF (1973) Mechanism of enzyme action. Annu Rev Biochem 42: 205 234

36. Frieden C, Hoeltzli SD, Bann JG (2004) The preparation of 19F-labeled proteins for NMR studies. Methods Enzymol 380: 400-415.

37. Andra KK, Bullinger JC, Bann JG, Eichhorn DM (2010) 2-Fluoro-I-histidine Acta Crystallogr Sect E Struct Rep Online 66: 02713.

38. H.J.C Y (1975) 19F and IH Nuclear Magnetic Resonance Studies of Ring fluorinated Imidazoles and Histidines. J Chem Soc., Perkin Trans 2: 928-934.

39. Klein DC, Kirk KL, Weller JL, Oka T, Parfitt A, et al. (1976) 2-Fluoro-L-histidine, an inhibitor of enzyme induction. Mol Pharmacol 12: 720-730.

40. Wimalasena DS, Cramer JC, Janowiak BE, Juris SJ, Melnyk RA, et al. (2007) Effect of 2-fluorohistidine labeling of the anthrax protective antigen on stability, pore formation, and translocation. Biochemistry 46: 14928-14936.

41. Wimalasena DS, Janowiak BE, Lovell S, Miyagi M, Sun J, et al. (2010) Evidence that histidine protonation of receptor-bound anthrax protective antigen is a trigger for pore formation. Biochemistry 49: 6973-6983.

42. Iyer V, Hu L, Schante CE, Vance D, Chadwick C, et al. (2013) Biophysical characterization and immunization studies of dominant negative inhibitor (DNI), a candidate anthrax toxin subunit vaccine. Human vaccines \& immunotherapeutics 9: 2362-2370.

43. Hu L, Joshi SB, Andra KK, Thakkar SV, Volkin DB, et al. (2012) Comparison of the structural stability and dynamic properties of recombinant anthrax protective antigen and its 2-fluorohistidine-labeled analogue. Journal of pharmaceutical sciences 101: 4118-4128.

44. Luck LA, Johnson C (2000) Fluorescence and 19F NMR evidence that phenylalanine, 3-L-fluorophenylalanine and 4-L-fluorophenylalanine bind to the L-leucine specific receptor of Escherichia coli. Protein Sci 9: 2573-2576.

45. Sixl F, King RW, Bracken M, Feeney J (1990) 19F-n.m.r. studies of ligand binding to 5-fluorotryptophan- and 3-fluorotyrosine-containing cyclic AMP receptor protein from Escherichia coli. Biochem J 266: 545-552. 